\title{
A KÉPEK MINT ,JELENTÉSTELI FELÜLETEK”: KÉPI DOKUMENTUMOK OSZTÁLYOZÁSELMÉLETI KÉRDÉSEI
}

\author{
DÁVID ADRIENNE \\ Fővárosi Szabó Ervin Könyvtár Budapest Gyűjtemény, \\ helyismereti tájékoztató könyvtáros
}

\begin{abstract}
ABSZTRAKT
A képek a vizualizáció által jelentést közvetítenek, jelentőségük korunkban megnőtt. A tudományban is fontos szerepet tölt be a képi információ: illusztrálásra, szavakkal nehezen kifejezhetô jelenségek bemutatására, modellezésre, diagnosztizálásra, és a valóság tükröztetésére, hiteles forrásként egyaránt használják. A képi dokumentumok speciális könyvtári dokumentumoknak tekinthetők, tartalmuk tükrözése az értelmezési lehetőségek sokfélesége miatt problematikus. A bennük hordozott információ reprezentálására a könyvtárak különféle tudásreprezentációs eszközöket - elsősorban kontrollált szótárakat, tárgyszavas, tezauruszokra épülő rendszereket - használnak. A szakértők a képek feldolgozásának jövőjét szinte mindannyian az ontológiák, a magas szintű szemantikával ellátott, különböző tudásforrásokat integrálni képes visszakereső rendszerek használatában látiák. A felhasználói igények és szokások figyelembe vétele alapvető egy könnyen használható, releváns információt nyújtó szolgáltatás kialakításához. A használók tartalomalakításba való bevonása által a rendszerben a felhasználói szemlélet és logika is érvényesülni tud. Tanulmányomban ugyanazon fénykép különböző könyvtári tudásreprezentációs eszközökkel való feldolgozásának bemutatásán keresztül szeretném bemutatni a képi tartalom tükrözésének hatékonyságát és kihívásait.
\end{abstract}

\section{A „képi fordulat”}

A képek jelentősége korunkban vitathatatlan és megkerülhetetlen, jelenlétük életünk minden területén jellemző. A képek „ősi kommunikációs médiumok”, melyek minden kultúrtörténeti korban jelen voltak. A barlangrajzoktól kezdve az első írásjeleken át a templomi ábrázolásokig, késóbb pedig az írásbeliség mellett, az írásos információ tartalmának kiegészítéseként, illusztrálásaként mindig is fontos szerepet töltött be a képi információ. A nyomtatás elterjedésével lehetôvé vált a képek sokszorosítása, mely azok nagyobb terjedését vonta maga után, majd a nyomdatechnika és a fényképészet technológiai fejlődésének köszönhetően a múlt századtól egy új korszak köszöntött be, amely a jó minőségben többszörözött képek exponenciális terjedését hozta el. Az ezredforduló óta már kifejezetten „képi fordulatról”2 beszélnek a szakemberek, hiszen a digitális fényképezés és a világháló adta lehetőségek a képi információ minden eddiginél szélesebb körű és nagyobb mennyiségű megjelenését vonta maga után. Ugyanakkor a digitalizáció bizonyos tulajdonságai miatt a képi információ valamelyest veszített hitelességéből, hi- 


\section{DÁVID ADRIENNE}

szen a képek manipulálhatóvá váltak, s ezáltal a kép objektivitása és dokumentum volta megkérdőjeleződött.

Az emberi gondolkodásban központi szerepet tölt be a vizualizáció, a megértés szempontjából könnyebben kezelhető a képi megjelenítés. A kép sajátossága, hogy az azon rögzített információ közvetítő (pl. nyelv) nélkül, érzékszervvel (szem) közvetlenül felfogható. A „képek lényege az a képességük, hogy jelentést tudnak közvetíteni érzéki tapasztalat útján. A jelek és a nyelv rögzített fogalmi meghatározások, és ezek csak a tulajdonképpeni jelentés külső héjai. [...] Forma nélkül egy kép a tudat számára semmilyen vizuális ismeretet nem közvetíthet. Ez azt jelenti, hogy a rendezett formák hordozzák a vizuális fogalmakat, amelyek olvashatóvá tesznek egy képet, és nem a konvencionálisan meghatározott jelek”3. A kép „közvetít” a világ és az ember között, ily módon a megismerés eszköze lehet, ugyanakkor minden befogadó számára egyéni utakat kínál fel az értelmezés területén. A képek ,jelentésteli felületek" , melyek értelmezése kulturális tapasztalatok alapján jön létre. A képet pásztázó tekintet végigjárja az egyes képelemeket, a világról alkotott saját addigi ismeretei alapján értelmezi a látványt és az egyes látványelemek közötti kapcsolatokat, majd mindezek alapján vonja le következtetéseit.

\section{A tudomány és a képek viszonya}

A tudás reprezentálásának alanyaként vizsgálnunk és folyamatosan követnünk kell a modern tudományt, illetve annak változásait, aktuális jelenségeit, hiszen ezeket tükröznünk kell tudásbázisainkban. A fejlődés gyorsasága mellett három fontos jellemzôt szeretnék kiemelni: a specializációt - mivel az egyes tudományágak szinte a végletekig specializálódnak, újabb és újabb, egyre szűkebb területeket lefedő résztudományágak jönnek létre saját kutatási területtel és speciális terminológiával -, a multi-illetve interdisz̨iplinaritás domináns jelenlétét, továbbá a technológia és tudomány összefonódását, melyek szintén speciális, új részterületeket hoznak létre, sajátos tudásanyaggal.

A tudomány és a képek viszonya már a legkorábbi időktől szoros összefüggésben van. A képi információ, a vizualizáció segítheti a befogadást, a megértést, sőt, a szöveg által nehezen reprezentálható tudásanyagot is szolgáltathat, így túlmutathat a puszta illusztráláson. Kép alatt e helyütt természetesen nem csupán fényképeket értünk: a különféle rajzok, ábrák, diagramok, a diagnosztikai eszközök által készített speciális képi információk stb. is ide sorolódnak. Tudományterületektől függően más-más szerepet tölthetnek be a képek a szöveges információk mellett. E tanulmány témája szempontjából elsôsorban a szöveg és a kép viszonyát vizsgáljuk.

Az illusztrálásra szánt képek nem önállóak, a szöveg könnyebb megértésére, az abban közölt információk kiegészítésére szolgálnak, és pontos szöveghelyhez kapcsolódnak, így „a szöveg egyfajta kiterjesztését nyújtják” ”. Az olyan tudományok esetében, mint például az orvostudomány vagy a botanika, az illusztrációk szavak által nem, vagy nehezen közvetíthető ismereteket, jelenségeket reprezentálnak, például különböző orvosi esetek vagy egyedi példányok bemutatásával. A matematika, fizika, nyelvészet területén statisztikákkal, diagramokkal, sematikus ábrázolásokkal találkozunk, ezek szintén 
A KÉPEK MINT ,JELENTÉSTELI FELÜLETEK”: KÉPI DOKUMENTUMOK OSZTÁLYOZÁSELMÉLETI KÉRDÉSEI

a szövegek kontextusában értelmezhetők, azok illusztrálására használatosak; itt a képek összefüggésbe hozhatók a tudományos tevékenységek egyes központi mozzanataival. Más területeken a képek a modellépitéssel hozhatók összefüggésbe, ilyen például a kémia, ahol a szavakkal nehezen leírható, de közvetlenül esetleg nem vizualizálható jelenségeket igyekeznek reprezentálni.

A technikai eszközök fejlődésével nő, és egyúttal egyszerűsödik a vizualizálás lehetősége például a különféle tervezéssel foglalkozó területeken (pl. építészet, autoCADprogram), vagy az orvosi diagnosztikában. A diagnosztikai esqközök (pl. ultrahangkészülék) által létrehozott képek értelmezéséhez viszont előzetes, speciális tudás szükséges.

Más esetekben a tudományok a képeknek azt a tulajdonságát használják ki, hogy képesek tükröżni a valóságot, sokszor a nyelvi kifejezésmódnál személetesebben, ezért bizonyos területeken forrásértékűnek, teljes értékű reprezentációs eszköznek tekinthetők. Ahogy Lehmann Miklós fogalmaz: „A valóság strukturáltsága esetenként jobban érvényesül a képeken, mint a szövegben, mivel a képek szemléletessé teszik a valóság elemeinek kapcsolódásait. E tekintetben a képek éppen a rendet, s nem a rendetlenséget tükrözik. [...] Szemben a szöveg lineáris rendjével, a képek szimultán, egyazon időben megjelenő rendet mutatnak: az a rendetlenség, melyet a nyelv elsődlegességét hangsúlyozó teoretikusok a képek hátrányos tulajdonságának tartanak, ebben az értelemben nem más, mint a rendetlenség rendje.” Ilyen jellegú képekkel például a történettudomány, a helyismeret/helytörténet területein is találkozhatunk.

\section{Képi dokumentumok tartalmi feltárásának kérdései}

A képi dokumentumok speciális könyvtári dokumentumoknak tekinthetôk. Tartalmuk hatékony reprezentálására és visszakeresésének biztosítására a különböző tartalomszolgáltató rendszerekben többféle módszer áll rendelkezésünkre. Megtalálni a képet, amely megfelel az igényeinknek egy nagy és összetett gyüjteményben esetenként igen bonyolult és időigényes feladat lehet. A képek feltárásának egyik fontos, elméleti kiinduló kérdése, hogy melyek azok az attribútumok, amelyek alapján keresni fogják ezeket a dokumentumokat. Ez nem triviális kérdés, hiszen „a vizuális forrás jelentése nagy részben függ annak a személynek az interpretációjától, aki nézi azt. Ugyanazon vizuális forrás különböző emberek által különböző módokon meghatározható, a személy céljától, hátterétôl és tapasztalataitól függően"”. Célravezető lehet megtalálni a megfelelő módszert a tartalmi feltáráshoz annak érdekében, hogy ezt a többféle értelmezhetőséget a lehető legnagyobb mértékben tükrözni tudjuk.

Képek tartalmi feltárására a hagyományos osztályozási rendszerek közül elsősorban a kontrollált szótárak, tárgyszavas, tezauruszokra épülő rendszerek használatosak. Ilyen például a Getty Vocabularies (a Getty Images Institute megosztott szótárai: http:/ /www.[-] getty.edu/research/tools/vocabularies), amely strukturált és sztenderdizált terminológiát biztosít a legkülönfélébb vizuális anyagok feldolgozásához. Az újabb kutatások és fejlesztések a trendekkel párhuzamosan a sæemantikus web irányába mutatnak. A tartalom feltárásának eszközeként a legoptimálisabb megoldást a képi dokumentumok számítógépes feltárása esetében a szakemberek elsősorban az ontológiák alkalmazásában látják. 


\section{Hagyományos feltáró rendszerek vs. ontológiák?}

Az ontológia kifejezés definiálására többféle meghatározás létezik. Az ismeret- és tudásmegosztás területén a fogalomalkotásnak, illetve a fogalom feltérképezésének a specifikációját, vagyis konkrét körülírását, megkülönböztetését jelenti. Azoknak a fogalmaknak és a fogalmak közötti viszonyoknak, kapcsolatoknak a feltérképezését fejezi ki, amelyek egy vagy több területre jellemzők, azon a szakterületen belül léteznek, tehát az adott téma ismereteinek, rendszerének, a létrehozott közös szókincsnek, közös tudásnak a reprezentációja. Az ontológia gyakorlatilag azt a szótárt adja meg, amellyel az adott ágensek egymás között kérdéseket és válaszokat tudnak megfogalmazni. Ezek a szótárak egymással összekapcsolódva egy szemantikus hálót formázhatnak. A magasabb szintű szemantikák gazdagabb tudásreprezentációt képesek nyújtani.

Az ontológiai alapú reprezentációs technológia egy számítógépes környezet, amelyben a gondolkodás szimulációja történik. A kifejezés a mesterséges intelligencia területéről származik, eszközei azok az intelligens szoftver-robotok, amelyek ezen ontológiákra támaszkodva tudnak a tudás reprezentálásában egy közvetítő, kommunikációs szerepet betölteni. Ezek az intelligens rendszerek képesek olyan hatásfokú információfeldolgozásra, amely hatékonyan tudja szimulálni az emberi gondolkodást.

Az ontológiák a tradicionális adatstruktúrák alternatívái, de nem váltják le azokat. A megosztott ontológiák a szemantikus web alapjai lehetnek, hiszen képesek a szabványos kifejezések és magyarázatok reprezentálására, így osztott tudásbázisként több(féle) rendszert is kiszolgálhatnak.

A. C. Benson szerint ${ }^{8}$ azok az ontológiai alapú tudásreprezentációs rendszerek, amelyek a mesterséges intelligencia technikáit alkalmazzák a könytári katalogizálás területén, magasabb szintű hatékonyságot érhetnek el a képi dokumentumok tartalmi feltárásánál. Ezek a rendszerek képesek további következtetések levonására a fogalmak és azok kapcsolatai alapján, így gazdagabb, relevánsabb találatokat tudnak prezentálni, mint a hagyományos, szóegyezésen alapuló keresővel ellátott rendszerek. Egy egyszerű példával illusztrálva: ha rögzítve van az ontológiában, hogy „XY egy fényképész”, illetve hogy „a fényképészek fényképezőgépet használnak”, akkor ezekből az információkból a rendszer maga vonja le a következtetést, hogy „XY fényképezőgépet használ”.

Benson tanulmányában az OntoPhoto nevű, kifejezetten képi dokumetumokra épülő ontológiai tudásbázis-kísérletrôl számol be. Meghatározása alapján az ontológia abban különbözik a hagyományos feltáró eszközöktől, hogy míg a katalóguscédula vagy a MARC rekord egyes dokumentumok szurrogátumai egy adott gyújteményen belül, és a bennük rögzített szavak nem szimbolikus reprezentációi a nyelvtól független tartalmaknak, addig az ontológián belül különbség van a tárolt szavak és azok jelentései között. Máshol így fogalmaz: amíg a MARC21 egy sablont szolgáltat tények meghatározására bibliográfiai objektumokról egy könyvtári integrált rendszeren belül, az ontológia „egy tájat fest le elénk” az adott témáról, egy szemantikai környezetet tár fel, amelyben az adott látvány értelmezhető.

Az ontológiának több szintje van, a felsőbb szintek az általánosabb fogalmakat fedik le, míg az alsóbb szintek specifikusabbak (1. ábra). 
A KÉPEK MINT ,JELENTÉSTELI FELÜLETEK”: KÉPI DOKUMENTUMOK OSZTÁLYOZÁSELMÉLETI KÉRDÉSEI

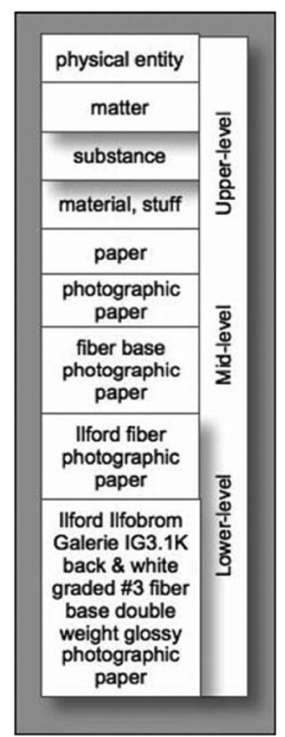

\section{1. ábra: A fénykép fizikai jellemzôit reprezentáló ontológiai szintek}

Visszatérve a jelentés és a szóalapú keresés problematikájára, ez különösen jelentős a fényképek esetében. A kép firikai valójában és tartalmilag is kapcsolatban van sok mindennel: fizikailag a környezetével (például hogy keretben van, a plafontól fél méterre, egy kiállítás kezdőképe stb.), tartalmilag is számos aspektus értelmezhető (például a képen szereplő konkrét személyek nevei, a szereplők közötti esetleges rokoni kapcsolat foka, a földrajzi helyszín, de akár a kamera és a fotó tárgyának kapcsolata is fontos lehet). Így fontos tényezôk a feltárás során a szerepek, vagyis azok az attribútumok, amelyek a dolgok jellemzőit határozzák meg, illetve a kapcsolatok. Ontológiáknál a szerepek hivatalosan kifejezhetők az ismeretszervező rendszerekben, s azok a szemantikus adatstruktúrában való elhelyezkedésüktől függnek, míg pl. a MARC-ban a szerepek jelentéstől független index-szavak.

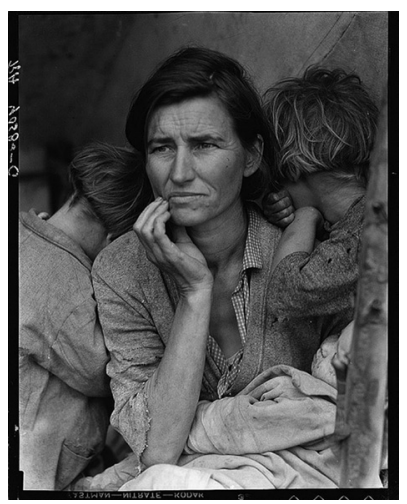

(new-type \{photographic print $\}$ photograph\})

(new-indv \{LC-USF34-T01-009058\} \{photographic print\})

(new-indv \{Dorothea Lange\} \{person\})

(new-indv-role \{image name $\{$ photograph\} \{string\})

(new-indv-role \{photographer $\}$ photograph $\}$ person\})

( $\mathrm{x}$-is-the-y-of- $\mathrm{z}$ ["Migrant Mother" $\}$ image name $\{$ LC-

USF34-T01-009058\})

( $\mathrm{x}$-is-the-y-of-z $\{$ Dorothea Lange $\}$ photographer $\{\mathrm{LC}$ USF34-T01-009058\})

2. ábra: A „Migrant Mother” címü képre vonatkož́ szerepek és kapcsolatok az OntoPhoto rendszerében 


\section{DÁVID ADRIENNE}

A 2. ábrán láthatók a szerepek és az egyes adatelemek közötti kapcsolatok, melyek nem determináltak. Az „,\{x az y-ja a z-nek\}”-típusú kapcsolat pedig többszörös kapcsolódás kifejezésére is módot ad. Látható, hogy szinte minden mindennel tetszés szerint összeköthető. Ez a tulajdonsága a rendszernek lehetővé teszi a képek esetében oly gyakori többszörös kontextus tükrözését.
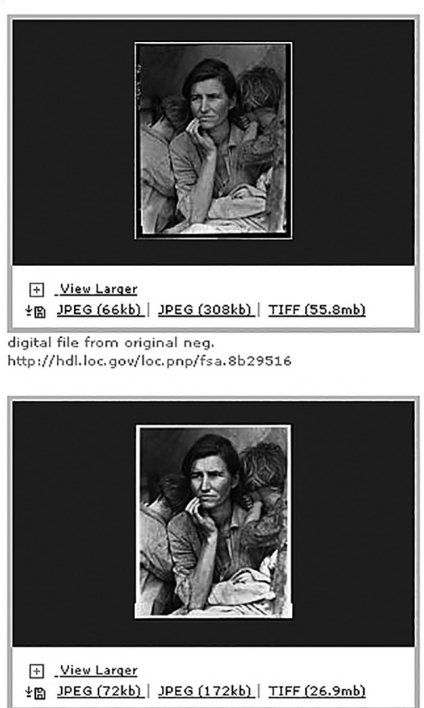

Destitute pea pickers in California. Mother of seven children. Age thirty-two. Nipomo, California

$$
\text { About This Item Obtaining Copies Access to Original }
$$

Title: Destitute pea pickers in California. Mother of seven children. Age thirty-two. Nipomo, California

Other Title: Migrant mother.

Creator(s): Lange, Dorothea, photographer

Date Created/Published: 1936 Feb. or Mar.

Medium: 1 negative : nitrate ; $4 \times 5$ in.

Summary: Photograph shows Florence Thompson with three of her children in a

photograph known as "Migrant Mother." For background information, see "Dorothea Lange's Migrant Mother' photographs ..." http://www.loc.gov/rr/print

llist/128_migm. htm

Reproduction Number: LC-DIG-fsa-8b29516 (digital file from original neg.)

LC-DIG-ppmsca-12883 (digital file from print, pre-conservation) LC-DIG-

ppmsca-23845 (digital file from print, post-conservation) LC-USF34-T01-009058-C (b\&w film dup. neg.) LC-USz62-95653 (b\&w film copy neg. of an unretouched file, showng thumb)

Rights Advisory: No known restrictions. For information, see U.S. Farm Security

Admistration/te of War Information Black \& White

Call Number: LC-USF34- 009058-C [P\&:P] LC-USF346-009058-C b\&w film

Call Number: LC-USF 34- 009058-C [P\&P] LC-USF346-00

Other Number: $] 339168$

Repository: Library of Congress Prints and Photographs Division washington, DC ://hdl.loc. gov/loc.pnp/pp. print

Notes:

- A copy transparency (LC-USF346-009058-C) and a copy safety negative

(LC-USF347-009058-C) are also in the collection.

- Digital file was made from the original nitrate negative for "Migrant Mother"
(LC-USF34-009058-C). The negative was retouched in the 1930 s to erase the thumb

3. ábra: A „Migrant mother" a Library of Congress digitális gyüjteményében.

\begin{tabular}{|c|c|c|c|c|}
\hline \multirow[t]{2}{*}{050} & 0 & 0 & a & LC-USF34- \\
\hline & 0 & 0 & b & $009058-\mathrm{C}$ \\
\hline \multirow[t]{2}{*}{051} & & & a & LC-USF346-009058-C \\
\hline & & & c & $b \& w$ film transparency \\
\hline \multirow[t]{2}{*}{051} & & & a & LC-USF347-009058-C \\
\hline & & & c & b\&w film safety neg. \\
\hline \multirow[t]{3}{*}{084} & & & a & J \\
\hline & & & b & 339168 \\
\hline & & & 2 & 2 \\
\hline \multirow[t]{2}{*}{100} & 1 & & a & Lange, Dorothea, \\
\hline & 1 & & e & photographer. \\
\hline \multirow[t]{2}{*}{245} & 1 & 0 & a & Destitute pea pickers in California. Mother of seven children. Age thirty-two. Nipomo, California \\
\hline & 1 & 0 & h & [graphic]. \\
\hline 246 & 1 & 3 & a & Migrant mother. \\
\hline 260 & & & c & 1936 Feb. or Mar. \\
\hline \multirow[t]{3}{*}{300} & & & a & 1 negative: \\
\hline & & & b & nitrate ; \\
\hline & & & c & $4 \times 5$ in. \\
\hline 500 & & & a & A copy transparency (LC-USF346-009058-C) and a copy safety negative (LC-USF347-009058-C) are also in the collection. \\
\hline 500 & & & a & $\begin{array}{l}\text { Digital file was made from the original nitrate negative for "Migrant Mother" (LC-USF34-009058-C). The negative was retouched in the } \\
1930 \text { to erase the thumb holding a tent pole in lower right hand corner. The file print made before the thumb was retouched can be } \\
\text { seen http: } / / \text { hdl.loc.gov/loc.pnp/ppmsca.12883. }\end{array}$ \\
\hline 500 & & & a & Title from caption card for negative. Title on print: "'Destitute pea pickers in California. A 32 year old mother of seven children." \\
\hline 520 & 0 & & a & $\begin{array}{l}\text { Photograph shows Florence Thompson with three of her children in a photograph known as "Migrant Mother." For background } \\
\text { information, see "Dorothea Lange's Migrant Mother' photographs ..." }\end{array}$ \\
\hline & 0 & & 6 & | http://www.loc.gov/rr/print/list/128_migm.html \\
\hline
\end{tabular}

4. ábra: A „Migrant mother” MARC-rekordjának részlete a Library of Congress digitális gyüjteményében. 
A KÉPEK MINT ,JELENTÉSTELI FELÜLETEK”: KÉPI DOKUMENTUMOK OSZTÁLYOZÁSELMÉLETI KÉRDÉSEI

Ugyanazon kép leírása (3. ábra) és MARC-rekordjának részlete (4. ábra) a Library of Congress rendszerében. A MARC-rekordban az adatelemek közötti kapcsolatokat az előre definiált sémában való elhelyezkedésük határozza meg (pl. a 100-as hívójelű mező „a” almezőjében a szerző neve szerepel, az „e” almezőben van rögzítve a szerep). Ez mindenképpen egy kötöttebb struktúra, mint az ontológia esetében.

Benson a digitális kép fényképként való értelmezését esetlegesnek tekinti, szerinte a digitális kép fotóként való értelmezésének összhangban kell lennie az aktuális nézetekkel az archiválás és az információtudomány területén. Amíg nincs megfelelő elméleti struktúra a digitális képek osztályozására, amely másnak határozza meg ezeket a dokumentumokat, mint fényképnek, addig csak a jelenlegi modellben lehet gondolkodni.

\section{Képek visszakerehetösége a felhasználó szemszögéböl}

A képek leírásának gyakorlata egy adott gyűjteményben egyrészt függ a gyűjtemény sajátosságaitól, másrészt a tárgyi feltárást végző személy saját tapasztalataitól. E tevékenységben sok a szubjektív elem, vagyis ugyanazt a képi dokumentumot különböző emberek más-más módon fogják feltárni - ha nem is teljesen különbözően -, ezért a leírásokban lesznek eltérések. A feltáró elsősorban azt fogja rögzíteni, ami szerinte fontos a visszakereséshez - például a nevek, a témakörök rögzítése szinte mindenki számára egyértelmű, de az érzelmek, az atmoszféra már kevésbé. Nehéz kérdés annak megítélése, hogy milyen információkat hasznos rögzíteni a felhasználó szempontjából.

\section{Keresési stratégiák képek esetében}

A felhasználókra jellemző keresési stratégiák vizsgálata és figyelembevétele a tartalmi feltárásnál hasznos lehet, ha a visszakeresés hatékonyságát növelni szeretnénk. Többféle vizsgálat zajlott e témában (pl. Markkula és Sormunen ${ }^{10}$; Chung és Yoon ${ }^{11}$; Youngok és Hsieh-Yee ${ }^{12}$ ), és a használók keresési stratégiáira vonatkozóan a levont következtetések nagyjából azonosak. Bár archívumtípustól és témától is függ, de elsősorban konkrét sz̨emélyekre, objektumokra és eseményekre (hely, idő is) keresnek az emberek. A témára való keresés is gyakori, de ez általában nem egy konkrét témára irányul, inkább a kontextusra vagy a háttérre vonatkozó információkra van igény. A keresési technikákat az egyszerűség jellemzi: előnyben részesítik az egyszerü keresést, általában egyetlen szót írnak be a keresőmezőbe, az összetett keresést annak nagyobb hatékonysága ellenére is kevesen alkalmazzák. A böngészés nagyon fontos szerepet kap, a felhasználók általában a keresésnél egyszerúbbnek találják ezt a módszert, mert segítségével kevesebb idôt igényel a kívánt kép megtalálása.

Markkula és Sormunen ${ }^{13}$ vizsgálatukban finn újságírók keresési stratégiáit elemezték egy újság fotóarchívumában. A képek feltárásának gyakorlata és a felhasználói igények összevetése során arra jutottak, hogy legnagyobb igény a konkrétan megnevezett objektumokra (emberek, szervezetek, események) van, ezt követik a híresemények fotói. Gondok akadtak a visszakereséssel az objektumtípusokra (állatok, növények, anonim személyek) való keresés során, illetve az adott téma tágabb kontextusára, szélesebb öszszefüggésekre való kereséskor (pl. „,valami a maffiáról”, „,valami a gazdasági válságról”), 


\section{DÁVID ADRIENNE}

továbbá a földrajzi formákra, portrékra is nehezen találtak rá a rendszerben. Az öszszetett keresésnél a beépített tezaurusz használatát túl bonyolultnak találták. A szerzők végkövetkeztetésként olyan témaspecifikus tezauruszok használatát javasolják az archivátoroknak, amelyek szemantikus térképként funkcionálhatnak (a vizsgálat lefolytatásakor még nem álltak rendelkezésre ilyen eszközök az újságírás területén). Az érzések, szimbolikus jelentések indexelését is fontosnak tartották, ám elismerték, hogy nehéz eldönteni, ezek közül mi lesz fontos a felhasználóknak.

Bannour és Hudelot ${ }^{14}$ tanulmányukban kifejtették, hogy az ontológiák alkalmazása a feltárásban hatékonyabbnak bizonyul az olyan típusú visszakereséseknél, ahol nem konkrétan megnevezett objektumra, hanem valamilyen általánosabb, kontextuális tartalomra kíváncsi a felhasználó, például „egy olyan képet keresek, amin autó van”, „egy éppen a vízből kiugró gyilkos bálnáról keresek fotót”, „,egy olyan képet keresek, amin a globális felmelegedést ábrázolják”. Mind a feltárásnál, mind pedig a visszakeresésnél fontos a kontextuális tudás, ennek legjobb segédeszköze pedig a magas szintû szemantikával ellátott, különböző tudásforrásokat integrálni képes képvisszakereső rendszer.

\section{Crowdsourcing ${ }^{15}$}

A felhasználói címkézés lehetőségének biztosítása módot ad arra, hogy a szabványos könyvtári tartalomfeltárás mellett a felhasználói szemmel fontosnak vélt adatok is rögzítésre kerülhessenek. Ha „fizikailag” el is különül a könyvtári tárgyszavaktól a felhasználói címkefelhő, ha keresni mindkettőben lehet, az nagy mértékben segíti a képek visszakeresését, a felhasználói szempontok és logika érvényesülését.

A korábban már példaként bemutatott „Migrant mother” című fénykép a Library of Congress gyűjteményének része. A szabványos könyvtári leírást és a kép digitalizált változatait megtaláljuk a könyvtár weboldalán. A leírásban megemlítik, hogy a képről esetleg további információk találhatók a könyvtár által a fotónak a Flickr közösségi képmegosztó oldalra feltöltött rekordjánál, a képhez link is elvezet.

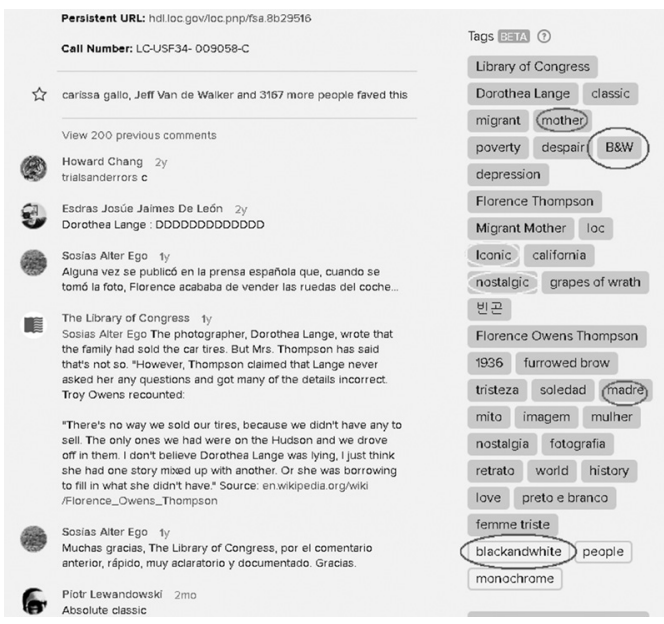

5. ábra: A „Migrant mother" adatlapja a Library of Congress Flickr-felületén 
A KÉPEK MINT ,JELENTÉSTELI FELÜLETEK”: KÉPI DOKUMENTUMOK OSZTÁLYOZÁSELMÉLETI KÉRDÉSEI

A Flick-re feltöltött képet a felhasználók kommentelhetik, címkézhetik (5. ábra). A címkefelhőt megvizsgálva látható, hogy azok meglehetősen következetlenek, például a $B \& W$ és a blackandwhite ugyanazt jelentik; egy-egy kifejezés több nyelven is megjelenhet (itt: mother és madre), és érdekes az is, hogy a hagyományos, könyvtárosi feltáró szemlélettől idegen, hangulatokat, érzéseket kifejező címkék is megjelennek (pl. nostalgic, iconic, love). Ez a sokféleség egyáltalán nem zavaró, és segítséget jelent abban, hogy az adott tartalmat a felhasználók a lehető legtöbb irányból megtalálhassák. Chung és Yoon ${ }^{16}$ a tagek (címkék) használatára vonatkozó vizsgálatukban nagyjából ugyanarra jutottak, mint amit az előző fejezetben láttunk, vagyis hogy a felhasználók a közösségi képmegosztó felületeken is az egyszerűségre törekedve keresnek, generikus, általános szintű fogalmakra, egy-egy szóra, kifejezésre. A felhasználói címkézés így a keresési szempontokat is képes tükrözni, hiszen nyilvánvalóan olyan címkékkel látják el a képeket, amelyekre maguk is keresnének az adott képre vonatkozóan.

A Library of Congress megoldása jó példa arra, hogyan oldható meg a szabványos könyvtári leírás biztosítása mellett, hogy a felhasználók is „,beleszólhassanak” a tartalmi feltárásba. A kétféle adatolás fizikailag elkülönül, ám kiegészítik egymást, és növelik a visszakeresés hatékonyságát azáltal, hogy a szabványos leírás és tárgyszavak mellett a felhasználói szemlélet és logika is érvényesülni tud.

\section{Irodalom és jegyzetek}

${ }^{1}$ TASNÁDI Róbert: Miről szólnak a képek?: sajtófotó, képjelentés, kontextus a média- és kommunikációkutatás nézőpontjából. Forrás: http://www.mediakutato.hu/cikk/2012_04_tel/[-] 08_mirol_szolnak_a_kepek [2016. január 8.]

${ }^{2}$ MITCHELL, William J. T.: Picture Theory: essays on verbal and visual representation. London, University of Chicago Press, 1994. 445 p.

${ }^{3}$ ARNHEIM, Rudolf: Visual Thinking. Berkeley, University of California Press, 1969. 345 p.

${ }^{4}$ FLUSSER, Vilém: A fotográfia filozófiája. Budapest, Tartóshullám, Belvedere, ELTE BTK, 1990. Forrás: http://www.artpool.hu/Flusser/Fotografia/01.html [2016. január 8.]

${ }^{5}$ LEHMANN Miklós: A képek szerepe a tudományban. Forrás: http://old.tok.elte.hu/tarstud/[-] filmuvtort_2001/lehmann.htm [2016. január 8.]

${ }^{6}$ LEHMANN Miklós: i. m.

${ }^{7}$ HOLLINK, L.: Semantic annotation for retrieval of visual resources (Doctoral dissertation, Dutch Research School for Information and Knowledge Systems, 2006). Forrás: http:/ [-] www.cs.vu.nl/ laurah/1/papers/ProefschriftLauraHollink.pdf [2016. január 8.]

${ }^{8}$ BENSON, Allen C.: OntoPhoto and the Role of Ontology in Organizing Knowledge. = Knowledge Organization, Vol. 38. No. 2. 2011. 79-95. p.

${ }^{9}$ BENSON, Allen C.: i. m.

${ }^{10}$ MARKKULA, Marjo-SORMUNEN, Eero: End-User Searching Challenges Indexing Practices in the Digital Newspaper Photo Archive. Forrás: http://www.sis.uta.fi/infim/julkaisut/[-] fire/End_user.pdf [2016. január 8.] 


\section{DÁVID ADRIENNE}

${ }^{11}$ CHUNG, E. - YOON, J.: Categorical and specificity differences between user-supplied tags and search query terms for images. = Information Research, Vol. 14. No. 3. paper 408. Forrás: http://informationr.net/ir/14-3/paper408.html [2016. január 8.]

${ }^{12}$ YOUNGOK, Choi - HSIEH-YEE, Ingrid: Finding Images in an Online Public Access Catalogue: Analysis of User Queries, Subject Headings, and Description Notes. = Canadian Journal Of Information \& Library Sciences, Vol. 34. No. 3. 2010. 271-295. p.

${ }^{13}$ MARKKULA, Marjo - SORMUNEN, Eero: i. m.

${ }^{14}$ BANNOUR, Hichem - HUDELOT, Céline: Towards ontologies for image interpretation and annotation. Forrás: http://citeseerx.ist.psu.edu/viewdoc/download?doi=10.1.1.403.6702[-] \&rep $=$ rep1\&type $=$ pdf [2016. január 8.]

${ }^{15}$ A crowdsourcing egy sajátos, általában online felületen keresztül végzett, önkéntes tevékenység, melynek során civil résztvevők különféle feladatokat végeznek el egy adott gyűjtemény számára. Ez lehet például adatgyűjtés és -feldolgozás, illetve már meglévő állományrészek feldolgozásában, adatolásában, a nyilvánossághoz történő közvetítésében való együttmúködés.

${ }^{16}$ CHUNG, E. - YOON, J.: i. m.

\section{A képek forrása}

A „Migrant mother” adatlapja a Library of Congress Flickr-felületén. Forrás: https://www.[-] flickr.com [2016. január 10.]

A „Migrant mother” MARC-rekordjának részlete a Library of Congress digitális gyújteményében. Forrás: http://www.loc.gov/pictures/item/fsa1998021539/PP/marc [2016. január 10.]

A „Migrant Mother” című kép a Library of Congress katalógusában. Forrás: http://www.[-] loc.gov/pictures/item/fsa1998021539 [2016. január 10.]

Dávid Adrienne 2008-2013 között az Országos Széchényi Könyvtár munkatársaként a Magyar Elektronikus Könyvtár könyvtárosa. Közreműködött a Magyar Digitális Képkönyvtár létrehozásában és a Digitális Képarchívum építésében. 2014 januárja óta a Fővárosi Szabó Ervin Könyvtár Budapest Gyűjteményének helyismereti tájékoztató könyvtárosa. Fő szakterülete a könyvtárak képi dokumentumainak digitalizálása, feldolgozása és hálózati megjelenítése. Az ELTE Irodalomtudományi Doktori Iskola Könyvtártudomány Doktori Programjának hallgatója. 